\title{
An Examination of Housing Affordability in Bauchi Metropolis
}

\author{
Ilekoin Olutoba Ayodele and Hamisu Abdulkadir Noma \\ Department of Estate Management, Federal Polytechnic, Bauchi
}

\begin{abstract}
This paper examines the concept of housing affordability in Yelwa, Bauchi metropolis. 200 questionnaires were administered to the people that reside in the study area. The study found that there is a significant relationship between household income and the amount of money paid for rent. The study further revealed that $74 \%$ of the household spends more than $30 \%$ of their household income on accommodation while $26 \%$ spends less than $30 \%$ of their household income on housing. This percentage is above the universally acceptable standard .This shows that housing is not affordable in the study area .
\end{abstract}

Keywords: affordable, market, income, household, finance

\section{Introduction}

Housing is central component of human settlement; it fulfills his indispensable need for accommodation. Housing has great effect on human's quality of life, physical condition, happiness and productivity. It importance is seen in both physical and economic development, environmental sustainability, alleviation of natural disaster .It is a very good resources for employment generation as well as wealth creation (UN- HABITAT 2006). Humans yearning for affordable and satisfactory housing have relationship with their needs for security and correct socio - economic class. Despite the above mentioned importance of housing to humans, countless numbers of people are still homeless, sufficient and affordable housing are not within the reach of many people that are living in urban areas of the less developed countries (Tipple, 2006). Consequently, the majority of people living in the urban areas of the less developed countries are living in houses whose conditions are appalling in terms of social, economic and health standards .Providing Good and affordable housing has continuously been a thing of concern to the people and governments of developing counties . The humans have the natural tendency to scrutinize, illustrate and offer solution to problems that face the human races, hence ; the human race have enacted many legislations, policies, tactics and many housing programs with the sole aim of providing standard and affordable housing for the people (Ajanlekoko, 2002 ). For instance, the government of Nigeria(a developing country) has created at least seven different housing programs between 1950 and 2000 in a bid to providing accommodation to its people (Ademiluyi and Raji,2008). In spite of the Government effort to provide adequate and decent accommodation to its citizenry, available evidence has shown that (1) the majority of the housing schemes are poorly conceived and not efficient thereby became unsuccessful in meeting the housing need of the targeted population, (2)the number of houses provided by government is much more less than those provided by the private sector and (3) government involvement in housing provision is not cost effective ( UN - HABITAT , 2006 ). Hence; it is the opinion of scholars that government should not involve itself with direct provision of housing, rather it should only create and enabling environment for housing provision to the private sector. This paper examines how affordable are the houses that are in Bauchi state housing market to its citizens, Yelwa, community in Bauchi metropolis is used as a case study .

\section{Chaarcacteristics of Housing Market}

The housing markets always go through delay in supply alteration all over the world as a result of the following uniqueness of the housing market that differentiated from other markets:

$\checkmark$ Immobility: Houses are stationary by nature; they cannot be moved from one place to another. This immobility uniqueness of housing makes its site fixed thereby making it impossible for the housing supply in one location to meet the housing demand of another location.

$\checkmark$ Durability: The houses are long-lasting because they are not easy to destroy, nature makes it supply to be comparatively permanent for a long period of time.

$\checkmark$ Heterogeneity: Houses are varied because it can be found in diverse types, shape, and dimension and even in structural design.

$\checkmark$ Huge Capital Outlay: houses are not purchasable at little capital. Unlike houses, Stocks and shares can easily be split in to smaller units at little capital. In most of the cases, for one to either supply or demand for house in the housing market, one has to borrow money from the financial institutions due to high amount of capital outlay that is required in housing provision. 


\section{Nigeria Housing Market}

There are basically two types of markets in the Nigeria housing market: the public sector market and the private sector market. The housing market can be differentiated by the types of tenure that exist in it; it can either be private tenure or public tenure, privately rented accommodation or publicly rented accommodation; the market can also be distinguished by its structural design which could be in form of :bungalow, flat, or duplex. The market is also being differentiated density such as: high, medium or low density areas. Income such as : low, medium, high income housing, types of structure, types of right, price, rent, quality, house hold size and social class of the house are also some of the characteristic that are used to differentiate the various types of housing market ( Agbola and Olatunbara , 2007). Nigeria housing market is controlled by the private sector because majority of the houses are built by individuals. In 2002, the federal Government of Nigeria noted that over 90 percent of the housing stock is built by the private sector FGN, 2002). The houses that are supplied in to the housing market by the private and public sectors are without the reach of an average Nigeria.

\section{Housing Demad In Nigeia}

Generally, any form of demand is controlled by many economic factors like, a boost in economic activities. In 2001, Nigeria housing shortfall stood at 14 million housing units (UN- habitat, 2006).The table below shows the projected deficit in the Nigeria housing market in the year 2002.

Projected housing needs (1991 - 2001)

\begin{tabular}{|l|l|l|l|}
\hline & Urban areas & Rural areas & total \\
\hline Housing stock, 1991('000 units) & 3,373 & 11,848 & 15,221 \\
\hline Projected no of households ,2001('000) & 7,289 & 15,295 & 22,584 \\
\hline Required output ,1991-2001('000) & 3,916 & 3,447 & 7,363 \\
\hline Required annual output, 1991-2001('000) & 391.6 & 344.7 & 736.3 \\
\hline
\end{tabular}

Source: (UN - Habitat, 2006)

In 2006, Nigeria population was $140,431,790$ with male population of $71,345,488$ and female of $69,086,302$, as of that year, the Nigerian housing stock was 10.7 million with housing deficit of 17 million. It means that for Nigeria to be able to house its population, additional 17 million houses must have been built in year 2006. Nigeria needed N59.5 before it would be able to bridge the gap of 17 million housing deficit of 17 million of 2006.

In Nigeria, the rate at which house is being demanded is much more low when compared to the rate at which it is being supplied. There is a large variance between the demand and supply in Nigeria housing market. The table below shows the estimated housing stock, by types in Nigeria in 1991.

Table 1: Projected housing stock by types in Nigeria in thousand (1991)

\begin{tabular}{|c|c|c|c|c|c|c|}
\hline & Urban & Urban & Rural & Rural & Total & Total \\
\hline & $\%$ & Units (millions ) & $\%$ & Units (millions ) & $\%$ & Units (millions ) \\
\hline Marionette & 2 & 67 & 0 & 12 & 1 & 79 \\
\hline Duplex & 3 & 101 & 0 & - & 1 & 101 \\
\hline Detached and bungalow & 10 & 337 & 20 & 2,289 & 17 & 2,627 \\
\hline Semi - detached & 2 & 67 & 1 & 60 & 1 & 127 \\
\hline Flat & 15 & 506 & 0 & - & 3 & 506 \\
\hline Tenement (room) & 65 & 2,194 & 77 & 9,200 & 74 & 11,393 \\
\hline Others & 3 & 101 & 2 & 287 & 3 & 388 \\
\hline TOTAL & 100 & 3,373 & 100 & 11,848 & 100 & 15,221 \\
\hline
\end{tabular}

Source: (UN-Habitat, 2006)

\section{Constriants of Housing Supply in Nigeria}

For Nigeria to well supply with sufficient accommodation, the following three major constraint of housing provision must be addressed:

A). access to finance: Inadequate access to fund for housing development is one of the principal problems that are confronting housing delivery in Nigeria. Nigerian mortgage industry is undeveloped and ineffective, between 1960 and 2009, the mortgage industry in the country made less than 100,000 transaction. The mortgage industry contribution to the nation's Gross Domestic Product (GDP) was about 0.05 of the nation's GDP while the nation real sector contributed $5 \%$ (World Bankt, 2009). This 0.05 contribution of mortgage industry to housing supply in Nigeria is far below the contributions that other countries mortgages institutions contribute to their GDPS. For instance, the mortgage industry contributed 77\% in USA, 80\% in UK, 50 in Hong Kong and $33 \%$ in Malaysia. Most house owners are not qualified to apply for loan because less than $5 \%$ of land in Nigeria have land titles (Efina, 2010).

B). difficulty in obtaining land title: In Nigeria, there is high cost of land registration and titling. Property registration and transfer account for $27.1 \%$ of the property value. This is the highest in the world when put side 
by side either the developing or the developed countries (The World Bank, 2009), To either register or transfer a property in Nigeria, 21 different procedures are involved with an average completion days of 274, in some states in Nigeria, the land registration or transfer processes take 2 to 3 years (Obunadike, 2003).

C. expensive building materials: Any material that is used for building purposes is known as building material. Many of these building materials are substances that occurred naturally in the environment, examples of building materials are clay, rock, and sand, wood. There are also building materials that do not occur naturally, examples of building material that do not occur naturally is any material or product that is made by man that is used for building purposes (Kubisch et al 2010). The following are the causes of incrementing the cost of building materials:

Table 2 Causes of Increment in the Cost of Building Material

\begin{tabular}{|l|}
\hline s/no causes of increment in the cost of building material \\
\hline 1. over dependence on imported building materials \\
2. inadequate and inefficient infrastructural facilities (road and rail way system etc) \\
3. shortage of locally manufactured building materials \\
4. lack of knowledgeable technical expertise \\
5. lack of consistent government policy \\
6. lack of indigenous technology for the production of building materials \\
7. rapid depreciation of the national currency \\
8. over pricing of building material cost of production \\
9. Lack of finance for new building material production factories \\
10. increase in the labour cost of production \\
11. Over pricing of contracts for the production of building materials
\end{tabular}

Source: Nigeria Housing Policy Document - (Kubisch et al 2010)

\section{Housing Affordability}

Affordable housing is that house that is suitable for the needs of a range of low to moderate income households and priced so that low and moderate incomes are able to meet their essential basic living cost . Affordable housing has also been seen as that which do not cost more than $30 \%$ of the income of the people that are inhabitant of that house (Andrews, 1998) The definition that is given to affordable housing normally centers on the correlation that is between housing expenditure and the house hold income . Financial institutions do not usually allow more than $30 \%$ of household income to be given as loan to any given household. House hold that pay more than $30 \%$ of its household income on housing is judged to be cost encumbered and would find it difficult to be able to find the money to pay for basic humans necessities such as food, clothing, transportation and medical care (Kubisch et al 2010). The literature has pass judgment on the $30 \%$ threshold as been illusory because for low income families to spend $30 \%$ of their income on housing would leave them with the inability to be able to purchase other basic necessities of life (Andrew , 19998 ) never the less, the 30 $\%$ rule of thumb is still the most used and acceptable indicator for measuring housing affordability . Housing affordability tries to set a standard on the maximum amount of money a given household should pay on accommodation that would not impose unnecessary burden on that household thereby allowing such house hold to be able to pay for other necessities of life. The following 4 key variables have been identified as factors that would determine the affordability of housing for any given household (Chartered Institute of housing, 1992):

a. Rent levels which will have an impact on the ability of a tenant to afford accommodation

b. Household income.

c. The type of household (the family make up such as single parents, couple, elderly etc)

d. D. whether the house hold is eligible to housing benefit.

Housing affordability is not the same with housing affordability finance, housing affordability is an indication of total poverty, it has to do with the households that do not have the money to afford minimum housing standard, these set of households need additional assistance before they could be housed while as housing finance affordability illustrates the cost problems that low and medium income households are confronted with due to high cost of financing (Bichi, 2002).

\section{Data and Methods}

Widespread variables data on the economic, social and demographic on household were collected. Data on housing such as costs, rents, size and qualities of houses were also obtained from the people of Bauchi metropolitan area. The data for this research work was obtained though structured questionnaire that was administered to chosen resident of Yelwal, Bauchi from July, 2014 to June, 2015. A total of 200 questionnaires were collected from the residence of Yelwa area of Bauchi metropolis, systematic sampling techniques was adopted to choose residential properties at every $20^{\text {th }}$ residential property in the study area. Suitable statistical techniques such as frequency table, percentages and chi-square were used to analysis the result. 


\section{Results and Discusion}

Table 3: monthly house hold income by monthly rent in Yelwal, Bauchi

\begin{tabular}{|c|c|c|c|c|c|c|c|c|c|}
\hline & \multicolumn{5}{|c|}{ Paired Differences } & \multirow{2}{*}{$\begin{array}{l}\mathrm{t} \\
\text { Mean } \\
\end{array}$} & \multirow{2}{*}{$\begin{array}{l}\text { df } \\
\text { Std. Deviation }\end{array}$} & \multirow{2}{*}{$\begin{array}{l}\text { Sig. (2-tailed) } \\
\text { Std. Error Mean }\end{array}$} \\
\hline & & Mean & Std. Deviation & Std. Error Mean & $95 \%$ Conf & dence Interval of the Difference & & & \\
\hline & & Lower & Upper & Lower & Upper & Lower & Upper & Lower & Upper \\
\hline Pair 1 & rent - income & -6.22000 & 1.39691 & .09878 & -6.41478 & -0.02522 & .62 .970 & 199 & .000 \\
\hline
\end{tabular}

The Paired-Samples T Test procedure compares the means of two variables: rent and house hold income that represents the same group at different times. The mean values for the two variables are displayed in the Paired Samples Statistics table. A low significance value for the t test which is -62.970 (typically less than 0.05 ) indicates that there is a significant difference between the two variables (rent and household income).

Table 4: percentage of household income spend on housing

\begin{tabular}{|l|l|l|}
\hline$\%$ of Household income spend on housing & No of household & $\%$ \\
\hline Above $30 \%$ of household income & 148 & $74 \%$ \\
Below 30\% of household income & 52 & $26 \%$ \\
\hline
\end{tabular}

Source: author field work (2015)

The table above shows that of all the 2000 household that participated in the administered questionnaire, 148 , which $74 \%$, spends more than $30 \%$ of their monthly income on housing while only 52 household, which is $26 \%$, spends less than $30 \%$ of their monthly income on housing in the study area .

\section{Conclusion}

This paper examines the housing problems general and housing affordability in particular in Yelwa area of Bauchi metropolis. 200 questionnaires were administered to the people of the study area. The study found that there is a significant relationship between household income and the amount of money paid for rent. The study further revealed that $74 \%$ of the house household spends more than $30 \%$ of their household income on accommodation while only $26 \%$ spends less than $30 \%$ of their household income on housing. This shows that housing is not affordable in the study area.

\section{References}

[1] Ademiluyi, A. I., \& Raji, B. A. (2008). Public and Private Developers as Agents in Urban Housing Delivery in Sub-Saharan Africa: The Situation in Lagos State. Humanity and Social Sciences Journal

[2] Agbola, T., Egunjobi, L., Qolatubara C.O. (2007) Housing Development and Management: A Book of readings. University of Ibadan.

[3] Ajanlekoko, J. S. (2001). Sustainable Housing Development in Nigeria - The Financial and Infrastructural Implication.

[4] Andrews O.N (1998). Trends in the Supply of Affordable Housing . Meeting America's Housing Needs (MAHD):A Habitat 11 Follow Up Project.

[5] Chartered Institute of Housing (1992) Rent Levels, Rent Structures and Affordability: A Guide for Local Authorities and Housing Associations . Chartered Institute of Housing, Coventry.

[6] Bichi K.M. (2002). Housing the Nigerian Population : Problems and Prospects . A Paper Printed to senior Executive Course No. 24 Participants at the Nigerian Institutes of Policy and Strategic Studies, Kuru, Jos, Nigeria.

[7] Boehm T.P. and Schlomann A.M(2001) Housing and weather Accumulation : International Impact low - income Home ownership Working Paper Series, Harvard: Joint Center for Housing Studies , Harvard University Efina(2010). Access to housing finance in Africa: Overview of the housing finance sector in Nigeria.p://www.efina.og.ng/assets/documents.

[8] Erguden s.(2001)Low-Cost Housing : Policies and Constraints in Developing countries. Paper presented at International Conference on Spartial Information for Sustainable Development, Nairobi Kenya, 2-5 October ,2001. Available on line at www.unchs.org .

[9] Federal Republic of Nigeria (2002) Official Gazette on the breakdown of the National and state Provisional Totals 2006 census, S.I. NO 23 of 2002, No. 24, Vol.94 Lagos $15^{\text {th }}$ May

[10] Kubisch, A. C., Auspos, P., Brown, P., \& Dewar, T. (2010).Voices from the field III: Lessons and challenges from two decades of community change efforts . Washington, DC: Aspen Institute Roundtable on Community Change.

[11] Obunadike, G.O. (2003). Land Administration in Anambra State. Paper Presented at the working luncheon organized by NIESV, Anambra State

[12] Branch at Tracy Hotels, Awka.

[13] Triple A.G. (2006). Ways Forward for Housing Supply in Developing Countries: An Oblique View, in A.I Okewole et al (eds). The Built Environment : Innovation Policy and Sustainable Development . Ota - Nigeia: Department of Architect.

[14] UN- HABITAT (2002)Regional Housing Issues Profile : Implementing Housig Right in SouthEaste Europe. Paper Presented to the Regional Consultation on working Cities Inclusive in Belgrade , 25-26 February by Scott Leckie

[15] UN-Habitat (2009). Preparation of structure plans for three cities in Anambra State namely Onitsha, Awka and Nnewi. Report 2007-2008. Retrieved from http://www.unhabitat.org/pmss.

[16] World Bank. (2009). What is Inclusive Growth? Note prepared by PRMED Policy Advisory Group. http://siteresources.worldbank.org/INTDEBTDEPT/ Resources/468980-1218567884549/WhatIsInclusiveGrowth20081230.pdf. 